\title{
Influence of Different Fertilizer Types on the Growth and Yield of Two Varieties Cucumber (Cucumis melo)
}

\author{
Lawal, B. A. $^{1^{*}} \quad$ Ilupeju, E. A. ${ }^{1} \quad$ Ojeleye, A. E. ${ }^{2} \quad$ Asafa, R. F. ${ }^{1} \quad$ Akanbi, W. B. $^{1}$ \\ 1.Department of Crop production and Soil Science, Ladoke Akintola University of Technology, Ogbomoso, Oyo \\ State, Nigeria \\ 2.Department of Agronomy, College of Agriculture, Osun State University, Osogbo
}

\begin{abstract}
The growth, yield and nutritional quality of Poinsett and Marketmore varieties of cucumber in response to compost and NPK fertilizer application were evaluated at the Teaching and Research Farm of the Ladoke Akintola University of Technology, Ogbomoso, Oyo State, Nigeria. The six fertilizer combinations are T1 (0 kg N), T2 (100\% NPK, $600 \mathrm{~kg} \mathrm{NPK} \mathrm{15:15:15),} \mathrm{T3} \mathrm{(100 \%} \mathrm{Tithonia} \mathrm{compost} \mathrm{(TC),} 5$ tons/ha), T4 (75\% NPK + 25\% TC), T5 (50\% NPK + 50\% TC) and T6 (25\% NPK+ 75\% TC). The treatments were arranged as $6 \times 2$ factorial scheme in Randomised Complete Block Design with three replicates. Data were collected on growth parameters, fruit yield, calcium content and iron content. Data collected were subjected to analysis of variance and difference among treatments means was computed using Least Significant Difference at 0.05 probability level. The results revealed that at the point of maximum growth Poinsett cucumber variety produced significant longer vine $(173.78 \mathrm{~cm})$; higher number of leaves $(23.56)$ and more robust stem girth $(3.01 \mathrm{~cm})$ than the other variety. At 8 weeks after sowing (WAS) the longest vine length $(216.67 \mathrm{~cm})$ and number of leaves $(29.33)$ were obtained from cucumber plants treated with 5 tons/ha. Varietal effect was not significant $(\mathrm{p} \leq 0.05)$ on cucumber fruit yield and firmness. The vine length, fruit girth, stem girth, number of leaves were significantly influenced by the application of 5 tons/ha. At $8 \mathrm{WAS}$, the longest vine $216.67 \mathrm{~cm}$ and highest number of leaves $(27.33)$ were recorded from 5 tons/ha, while the widest stem girth $(2.10 \mathrm{~cm})$ was gotten from $50 \% \mathrm{NPK}+50 \%$ TC treated cucumber. Fruit yield was significantly improved by the application of different combination of fertilizer. Plant that received fertilizer had significant better fruit yield compared with non-fertilized one. However, the use of $50 \% \mathrm{NPK}+50 \%$ TC gave the highest fruit yield. The study concluded that combine application of $300 \mathrm{~kg}$ NPK +2.5 ton/ha TC would be sufficient for production of the two varieties tried in this study.
\end{abstract}

Keywords: Cucumber; farmyard manure; inorganic fertilizer; growth; yield.

DOI: $10.7176 / \mathrm{JBAH} / 9-14-03$

Publication date:July $31^{\text {st }} 2019$

\section{INTRODUCTION}

Cucumber (Cucumis sativus L.) is an ancient vegetable and one of the most important members of the Cucubitaceae family (Eifediyi and Remison, 2009a). Cucumber is a widely cultivated plant for its fruits which are a rich source of minerals and vitamins, eaten fresh in salads as a supplement with other vegetables. It is the second most important vegetable crop after tomato in Western Europe (Eifediyi and Remison, 2010). In tropical Africa, its place has not been ranked because of limited use. Production of high yield and good quality under open field condition need proper handling, especially when using organic manure (Peyvastet al, (2008); Abdelaziz, (2010)). Fertile soils are used for the cultivation of cucumber because infertile soils produced bitter and misshapen fruits which are often rejected by consumers. Bush fallowing has been an efficient, balanced and sustainable agricultural system for soil productivity and fertility restoration in the tropics (Ayoola and Adeniran, 2006), but as a result of increase in the population, the fallowing periods have decreased and this has an adverse effect on the fertility restoration, leading to poor yields of crops. Therefore, the use of external inputs in the form of fertilizer has become imperative. Farmyard manure has been used as a soil conditioner since ancient times and its benefits have not been fully harnessed due to large quantities required in order to satisfy the nutritional needs of crops (Makinde et al. (2007); Eifediyi and Remison (2010). The needs for renewable forms of energy and reduced cost of fertilizer have revived the use of organic manures worldwide (Ayoola and Adeniran, 2006). Improvement in environmental conditions and public health are important reasons for advocating increased use of organic materials (Ojeniyi, 2000; Eifediyi and Remison, 2010). However, because it is bulky, the cost of transportation and handling constitute a constraint to its use by peasant farmers. Therefore, use of compost, a stable form of organic fertilizer which release nutrients slowly, steadily and activates soil microbial biomass (Belay et al. 2001) has been severally advocated. Hence, this trial aimed at testing sole and combined application of mineral and compost fertilizers on cucumber growth and yield.

\section{MATERIALS AND METHODS}

The field experiments were conducted between in 2016 at the Teaching and Research Farm, Ladoke Akintola University of Technology, Ogbomoso, Nigeria. Ogbomoso is on latitude $8^{0} 10^{1} \mathrm{~N}$ and longitude $4^{0} 10^{1} \mathrm{E}$ in the 
Guinea Savannah zone of southwest Nigeria. The climate of Ogbomoso is mostly influenced by the northeast trade wind, which is characterized with cold but drying effect starting from November till March and southwest trade wind, which is warm and moist from April to October. The rainfall pattern is bimodal with peaks in the months of July and September. Annual amounts of rainfall range between $1150 \mathrm{~mm}$ and $1250 \mathrm{~mm}$. Rainfall stabilizes around May and stops around October, with a dry period between November and April. The temperature regime is high all year round. The mean minimum temperature is $28^{\circ} \mathrm{C}$ while the maximum is $33{ }^{\circ} \mathrm{C}$ with high relative humidity of about $74 \%$ all year round except in January when the dry wind blows from the north.

Prior to land preparation, soil samples from the experimental plot were collected and mixed. The soil was air dried and sieved through $2 \mathrm{~mm}$ sieve and analyzed for their nutrient compositions. Samples were analyzed for physical and chemical properties: soil particle size was determined by Bouyoucos method (Bouyoucos, 1962). Soil $\mathrm{pH}$ in $\mathrm{H}_{2} \mathrm{O}$ (1:1) was determined using laboratory apparatus. Soil organic carbon was determined by Walkley Black modified method (Black, 1965). Available phosphorus and total nitrogen was determined separately by Technicon method while exchangeable $\mathrm{Ca}, \mathrm{Mg}, \mathrm{K}, \mathrm{Na}$ and effective Cation Exchangeable Capacity of the soil was determined using Atomic Absorption Spectrophotometer.

The treatments involved two varieties of cucumber (Poinsett and Marketmore) and six fertilizer combinations (T1 (0 kg N), T2 (100\% NPK, $600 \mathrm{~kg}$ NPK 15:15:15), T3 (100\% Tithonia compost (TC), 5 tons/ha), T4 (75\% NPK + 25\% TC), T5 (50\% NPK + 50\% TC) and T6 (25\% NPK+ 75\% TC)). Each of the treatment supplied $90 \mathrm{~kg} \mathrm{~N} / \mathrm{ha}$ except the control. The seeds of the cucumber were obtained from National Seed Centre, Kano. The treatments were factorially combined to give 12 combinations arranged in a Randomized Complete Block Design with three replicates. The experimental site was manually cleared and 36 raised beds were made manually. Each bed was $3 \times 3 \mathrm{~m}\left(9 \mathrm{~m}^{2}\right)$ and the crops were spaced $0.6 \mathrm{~m}$ within and $1 \mathrm{~m}$ between rows to give 16,667 plants/ha.

Cucumber seeds were sown directly to the field at the rate of three seeds per hole. Supplying and thinning were done 2 weeks after sowing (WAS). Weeding was carried out as it became necessary by hoeing. Insect pests were controlled by applying Cypermethrine at $40 \mathrm{ml}$ per 20 litres of water. Spraying was at two weeks interval starting from 2 WAS. Five inner plants per plot were tagged and assessed for growth parameters which are number of leaves, vine length, stem girth and leaf area. Number of leaves was obtained by counting each green and functional leaf that existed on the plant at each sampling occasion. The plant height was measured through the use of meter rule and recorded. The fruit yield and yield parameters taken included fruit yield per plant and plot, fruit firmness and total fruit yield in tone per hectare. The fruit firmness was ranked by a panel of five who ranked within a range of 1-5, least to most firm in that order. Average later computed and reported.

Data collected were analyzed using Standard Analysis System (SAS, 2011) for analysis of variance. Difference among treatments means was compared using Least Significance Differences (LSD) at 0.05 probability level.

\section{RESULTS}

Vine length of cucumber was significantly influenced $(\mathrm{P} \leq 0.05)$ by fertilizer types and variety (Table 1$)$. Fertilizer type applied significantly increased the length of cucumber vine as growth progresses. At 4 weeks after sowing (WAS), the longest vine $85.67 \mathrm{~cm}$ recorded from T6 was followed by $70.82 \mathrm{~cm}$ from T5 treated respectively. The shortest vine length $27.50 \mathrm{~cm}$ was recorded from control treatment plots. At 6 WAS, the longest vine length $(122.00 \mathrm{~cm})$ was obtained from T3 plots followed by $106.17 \mathrm{~cm}$ from T5 treated plants while the shortest $(67.83 \mathrm{~cm})$ was from T4 treated cucumber. At 8 WAS, the longest vine $216.67 \mathrm{~cm}$ was recorded from T3 while the shortest vine $(137.50 \mathrm{~cm})$ was obtained from T1 treated cucumber. Across the weeks of data collection, vine length of Poinsett variety was longer, $(68.68,105.28$ and $173.78 \mathrm{~cm}$ respectively) than Marketmore (45.39, 81.67 and $165.28 \mathrm{~cm}$ respectively).

Fertilizer type applied significantly increased the stem girth of cucumber vine (Table 2). At 4 and 8 WAS, there was no significant difference in the stem girth of cucumber plant irrespective of the fertilizer type applied. However, at 6 WAS, the widest girth $2.12 \mathrm{~cm}$ was obtained from T5 was followed by $2.10 \mathrm{~cm}$ from T4 treated plants. At 4 WAS, there was no significant difference in the girth of cucumber plant irrespective of the variety. At 6 and $8 \mathrm{WAS}$, variety of cucumber influenced the stem girth significantly $(\mathrm{P} \leq 0.05)$. Poinsett had wider stem girth (2.10 and $3.01 \mathrm{~cm}$ respectively) compared with Marketmore (1.79 and $2.14 \mathrm{~cm}$ respectively).

The fertilizer type applied significantly increased the number of leaves on cucumber plant (Table 3). At 4 WAS, the highest mean number of leaves (6.75) was recorded from T5, followed by 5.80 from T2 treated plants. The least number of leaves 4.37 was obtained from cucumber treated with T6. At 6 WAS, the highest mean number of leaves 24.67 obtained from T3 was followed by 23.83 from T2 treatment respectively while the least mean number of leaves 13.17 was from T6 treated cucumber. At 8 WAS, cucumber plants treated with T3 treatment produced the highest mean number of leaves (29.33) while the least (17.83) was recorded from application of T6 treatment. In respect of varietal influence, there was no significant difference in the mean number of leaves on cucumber plant at 4WAS. However, at 6 and $8 \mathrm{WAS}$, there was significance difference in 
the number of leaves on cucumber plant with respect to the variety sowed. The fertilizer type applied significantly increased the mean leaf area of cucumber plant compared with control treatment at 4 and 6 WAP only (Table 4). But varietal effect on leaf area was only significant at 8 WAS.

Fruit yield of cucumber ( $\mathrm{t} / \mathrm{ha}$ ) was significantly influenced $(\mathrm{P} \leq 0.05 \%)$ by fertilizer and variety type (Figure 1 and 2). The highest fruit yield (23.3 t/ha) harvested from T5 treated cucumber was not significantly higher than yield from other fertilizer type except that of control treated $(15.5 \mathrm{t} / \mathrm{ha})$. Fruit yield from Marketmore $(21.7 \mathrm{t} / \mathrm{ha})$ was significantly higher than produce of Poinsett $(20.8 \mathrm{t} / \mathrm{ha})$. Both fertilizer and variety types did not have significant influence on fruit firmness (Figure 3 and 4 ) of cucumber.

\section{DISCUSSION}

Cucumber growth parameters were strongly influenced by sole and combined application of Tithonia compost and fertilizer and the yield was highest with the combination. Cucumber plant had enough nutrients for rapid growth and development considering the composition of the Tithonia compost which was incorporated into the soil during land preparation. It was observed that the higher the nutrients applied, the higher the vine length and number of leaves produced per plant. The vigorous growth in cucumber which was experienced during the growing period as evidenced in the vine length and number of leaves produced per plant was in agreement with Eifediyi and Remison, (2010) who reported that nutrients from mineral fertilizers enhanced the establishment of crops while those from the mineralization of organic matter promoted yield when manures and fertilizers were combined, Kamil et al. (2015) also reported an increase in the growth of cucumber from the application of organic and inorganic fertilizer.

The yield response from the experiment was in agreement with the reports of Murwira and Kirchman, (1993) and Eifediyi, and Remison, (2009b) who observed increased yield of crops through the combination of organic and inorganic fertilizer. Furthermore, the findings of this research are also in agreement with Kamil et al., (2015), who reported that the application of organic and inorganic fertilizer increased the yield of cucumber. The addition of Tithonia compost increased the water holding capacity and reduced the incidence of erosion thereby making more nutrients available to plant from the soil (Eifediyi, and Remison, 2010; Eifediyi et al., 2012). Bayu et al. (2006) and Eifediyi and Remison (2010) also reported that sorghum yield increased when 5 tons per hectare of farmyard manure was combined with $20 \mathrm{~kg} \mathrm{~N}+10 \mathrm{~kg} P$ ha- 1 . The combination of Tithonia compost and inorganic fertilizer significantly influenced cucumber yields compared to sole application of Tithonia compost or fertilizer.

\section{CONCLUSION}

This study has clearly shown that cucumber growth can be promoted by the combined application of Tithonia compost and inorganic fertilizer. The study concluded that combine application of $300 \mathrm{~kg} \mathrm{NPK}$ and 2.5 ton/ha Tithonia compost would be sufficient for production of the two varieties of cucumber tried in this study.

\section{REFERENCES}

Abdelaziz, I. M. E. (2010). Effect of different microorganisms and substrates on yield and fruit quality of cucumber in hydroponics system. Dissertation in partial fulfilment of the requirements of the degree of Doctor (Ph.D). Mendel University in Brno.

Ayoola, O. T. and Adeniyan, O. N. (2006). Influence of poultry manure and NPK fertilizer on yield and yield components of crops under different cropping systems in south west Nigeria. African Journal of Biotechnology 5(15): 1386-1392.

Bayu, W., N. F. G. Rethman, P. S. Hammes and Alemu, G. (2006). Effects of Farmyard Manure and Inorganic Fertilizers on Sorghum Growth, Yield, and Nitrogen Use in a Semi-Arid Area of Ethiopia. Journal of Plant Nutrition 29(2): 391-407

Belay, A., A. S. Claassens, F. C. Wehner and De Beer, J. M. (2001). Influence of residual manure on selected nutrient elements and microbial composition of soil under long-term crop rotation. South African Journal of Plant and Soil 18(1) 1-6.

Black C. A. (1965). Methods of soil Analysis. Agronomy No. 9 Part 2, Am. Soc. Agron. 2: 5-10

Bouyoucos G. J. (1962). Hydrometer method improved for making particle size analysis of soil. Agronomy Journal, 54(5): 464-465.

Eifediyi, E. K. and Remison, S. U. (2009a). Effect of Time of Planting on the Growth and Yield of Five Varieties of Cucumber (Cucumis sativus L.) Report and Opinion 1(5) 81-90

Eifediyi, E. K. and Remison, S. U. (2009a). The Effects of Inorganic Fertilizer on the Yield of Two Varieties of Cucumber (Cucumis sativus L.). Report and Opinion 1(5) 74-80.

Eifediyi, E. K. and Remison, S. U. (2010). Growth and yield of cucumber (Cucumis sativus L.) as influenced by farmyard manure and inorganic fertilizer. Journal of Plant Breeding and Crop Science 2(7): 216-220

Eifediyi, E. K., Ihenyen,J. O. and Ojiekpon, I. F. (2012). Evaluation of the effects of rubber factory effluent and 
NPK fertilizer on the performance of cucumber (Cucumis sativus L.). Nigerian Journal of Agriculture, Food and Environment 8(4):51-57

Kamil, S. S., Sarkawt, A. A., Ismael, A. H. and Pshtiwan, H. A. (2015). Effect of Bio-Fertilizer and Chemical Fertilizer on Growth and Yield in Cucumber (Cucumis sativus L.) in Green House Condition. AmericanEurasian J. Agric. and Environ. Sci., 15(3): 353-358.

Murwira, H. K and Kirchmann, H. (1993). Nitrogen dynamics and maize growth in a Zimbabwean sandy soil under manure fertilization. Communications in Soil Science and Plant Analysis, 24:17-18, 2343-2359.

Makinde E.A., Ayoola, O.T. and Akande, M.O. (2007). Effects of Organo-mineral Fertilizer Application on the Growth and Yield of 'Egusi' Melon. Australian Journal of Basic and Applied Sciences 1(1): 15-19.

Ojeniyi, S. O. (2000). Effect of goat manure on soil nutrients and okra yield in a rain forest area of Nigeria. Applied Tropical Agriculture., 5:20-23.

Peyvast, G., Olfati, J. A., Madeni, S., Forghani, A. (2008).Effect of vermicompost on the growth and yield of spinach (Spinacia oleracea L.). Journal of food, agriculture and environment 2008 6(1): 110-113.

SAS Institute (2011). SAS Propriety Software Release 9.3 SAS Institute Inc, Cary NC

Table 1: Influence of fertilizer and varietal type on vine length $(\mathrm{cm})$ of cucumber

\begin{tabular}{lccc}
\hline Fertilizer (T)/ & \multicolumn{3}{c}{ Weeks after planting } \\
\cline { 2 - 4 } varietal (V) Types & 4 & 6 & 8 \\
\hline $0 \mathrm{~kg} \mathrm{~N} / \mathrm{ha}$ & $27.50 \mathrm{~d}$ & $72.83 \mathrm{~d}$ & $137.50 \mathrm{e}$ \\
$100 \%$ NPK & $47.00 \mathrm{c}$ & $96.83 \mathrm{c}$ & $187.83 \mathrm{~b}$ \\
$100 \%$ Tithonia compost (TC) & $67.90 \mathrm{~b}$ & $122.00 \mathrm{a}$ & $216.67 \mathrm{a}$ \\
$50 \% \mathrm{NPK}+50 \% \mathrm{TC}$ & $43.33 \mathrm{c}$ & $67.83 \mathrm{e}$ & $138.83 \mathrm{e}$ \\
$75 \% \mathrm{NPK}+25 \% \mathrm{TC}$ & $70.82 \mathrm{~b}$ & $106.17 \mathrm{~b}$ & $181.83 \mathrm{c}$ \\
$25 \% \mathrm{NPK}+75 \% \mathrm{TC}$ & $85.67 \mathrm{a}$ & $95.17 \mathrm{c}$ & $154.50 \mathrm{~d}$ \\
$\mathrm{~T}$ & 26.12 & & $173.78 \mathrm{a}$ \\
Poinsett & $68.68 \mathrm{a}$ & $105.28 \mathrm{a}$ & $165.28 \mathrm{~b}$ \\
Marketmore & $45.39 \mathrm{~b}$ & $81.67 \mathrm{~b}$ & 46.32 \\
$\mathrm{~V}$ & 24.65 & 34.45 & 165.28 \\
$\mathrm{~T} * \mathrm{~V}$ & 441.07 & 1295.37 & \\
\hline
\end{tabular}

Means with the same alphabet in the same column are not significantly different

Table 2: Effect of fertilizer and varietal type on stem girth of cucumber

\begin{tabular}{lccc}
\hline Fertilizer (T)/ & \multicolumn{3}{c}{ Weeks after planting } \\
\cline { 2 - 4 } varietal (V) Types & 4 & 6 & $2.55 \mathrm{a}$ \\
\hline 0 kg N/ha & $1.00 \mathrm{a}$ & $1.55 \mathrm{c}$ & $2.45 \mathrm{a}$ \\
$100 \%$ NPK & $1.00 \mathrm{a}$ & $2.15 \mathrm{a}$ & $2.85 \mathrm{a}$ \\
$100 \%$ Tithonia compost (TC) & $1.00 \mathrm{a}$ & $2.10 \mathrm{a}$ & $2.75 \mathrm{a}$ \\
$50 \%$ NPK + 50\% TC & $1.00 \mathrm{a}$ & $2.00 \mathrm{a}$ & $2.48 \mathrm{a}$ \\
$75 \%$ NPK + 25\% TC & $1.00 \mathrm{a}$ & $2.12 \mathrm{a}$ & $2.37 \mathrm{a}$ \\
$25 \%$ NPK + 75\% TC & $1.00 \mathrm{a}$ & $1.75 \mathrm{bc}$ & Ns \\
T & $\mathrm{ns}$ & 0.12 & $3.01 \mathrm{a}$ \\
Poinsett & $1.00 \mathrm{a}$ & $2.10 \mathrm{a}$ & $2.14 \mathrm{~b}$ \\
Marketmore & $1.00 \mathrm{a}$ & $1.79 \mathrm{~b}$ & \\
V & $\mathrm{ns}$ & & 4.15 \\
T*V & $\mathrm{ns}$ & 10.06 & \\
\hline
\end{tabular}

Means with the same alphabet in the same column are not significantly different 
Table 3: Influence of fertilizer and variety on number of leaves of cucumber

\begin{tabular}{lccc}
\hline Fertilizer (T)/ & \multicolumn{3}{c}{ Weeks after planting } \\
\cline { 2 - 4 } varietal (V) Types & 4 & 6 & 8 \\
\hline 0 kg N/ha & $3.83 \mathrm{c}$ & $14.50 \mathrm{c}$ & $23.92 \mathrm{f}$ \\
$100 \%$ NPK & $5.80 \mathrm{~b}$ & $23.83 \mathrm{a}$ & $29.33 \mathrm{a}$ \\
$100 \%$ Tithonia compost (TC) & $5.65 \mathrm{~b}$ & $24.67 \mathrm{a}$ & $19.33 \mathrm{~d}$ \\
$50 \% \mathrm{NPK}+50 \%$ TC & $3.80 \mathrm{c}$ & $14.60 \mathrm{c}$ & $21.50 \mathrm{c}$ \\
$75 \% \mathrm{NPK}+25 \%$ TC & $6.75 \mathrm{a}$ & $18.45 \mathrm{~b}$ & $17.83 \mathrm{e}$ \\
$25 \% \mathrm{NPK}+75 \% \mathrm{TC}$ & $4.37 \mathrm{c}$ & $13.17 \mathrm{c}$ & $23.56 \mathrm{a}$ \\
$\mathrm{T}$ & 2.12 & & $18.53 \mathrm{~b}$ \\
Poinsett & $4.83 \mathrm{a}$ & $17.17 \mathrm{~b}$ & 375.75 \\
Marketmore & $5.23 \mathrm{a}$ & $19.24 \mathrm{a}$ & \\
V & & & 27.86 \\
$\mathrm{~T}$
\end{tabular}

Means with the same alphabet in the same column are not significantly different.

Table 4: Influence of fertilizer types on leaf area of cucumber

\begin{tabular}{lccc}
\hline Fertilizer (T)/ & \multicolumn{3}{c}{ Weeks after planting } \\
varietal (V) Types & 4 & 6 & 8 \\
\hline $0 \mathrm{~kg} \mathrm{~N} / \mathrm{ha}$ & $242.00 \mathrm{c}$ & $342.0 \mathrm{~d}$ & $1400 \mathrm{a}$ \\
$100 \%$ NPK & $580.67 \mathrm{a}$ & $757.17 \mathrm{a}$ & $2182 \mathrm{a}$ \\
$100 \%$ Tithonia compost (TC) & $538.17 \mathrm{a}$ & $704.50 \mathrm{a}$ & $1533 \mathrm{a}$ \\
$50 \% \mathrm{NPK}+50 \% \mathrm{TC}$ & $392.33 \mathrm{~b}$ & $495.17 \mathrm{c}$ & $1780 \mathrm{a}$ \\
$75 \% \mathrm{NPK}+25 \% \mathrm{TC}$ & $548.0 \mathrm{a}$ & $634.33 \mathrm{~b}$ & $4078 \mathrm{a}$ \\
$25 \% \mathrm{NPK}+75 \% \mathrm{TC}$ & $420.17 \mathrm{~b}$ & $524.17 \mathrm{c}$ & $1465.2 \mathrm{a}$ \\
$\mathrm{T}$ & & & $2727.7 \mathrm{a}$ \\
Poinsett & $453.44 \mathrm{a}$ & $547.17 \mathrm{~b}$ & $\mathrm{~ns}$ \\
Marketmore & $453.67 \mathrm{a}$ & $605.28 \mathrm{a}$ & $\mathrm{ns}$ \\
V & $\mathrm{ns}$ & 32.21 & 22.27 \\
$\mathrm{~T} * \mathrm{~V}$ & 8.28 & $\mathrm{n}$ & \\
\hline
\end{tabular}

Means with the same alphabet in the same column are not significantly different.

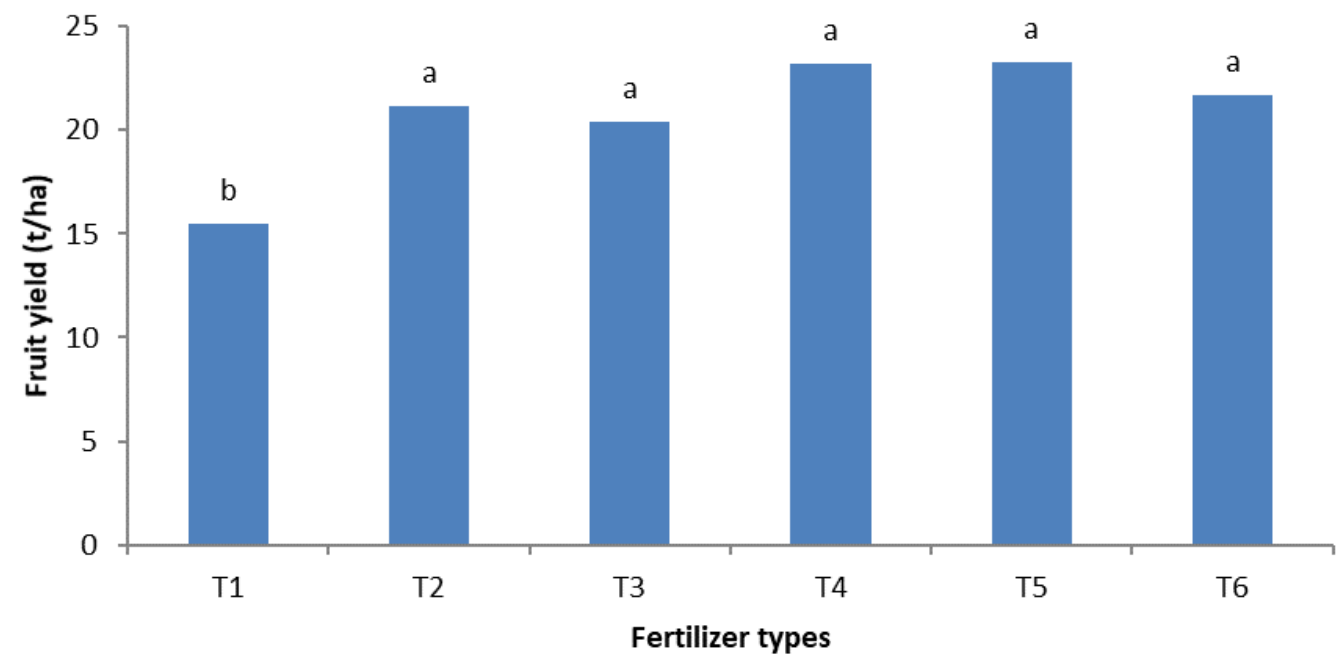

Fig 1: Influence of fertilizer types on cucumber fruit yield

Note: Bars with the same letter are not significantly different.

$\mathrm{T} 1=0 \mathrm{~kg} \mathrm{~N} / \mathrm{ha} ; \mathrm{T} 2=100 \% \mathrm{NPK} ; \mathrm{T} 3=100 \%$ Tithonia compost (TC);

$\mathrm{T} 4=50 \% \mathrm{NPK}+50 \% \mathrm{TC} ; \mathrm{T} 5=75 \% \mathrm{NPK}+25 \% \mathrm{TC} ; \mathrm{T} 6=25 \% \mathrm{NPK}+75 \% \mathrm{TC}$ 
b

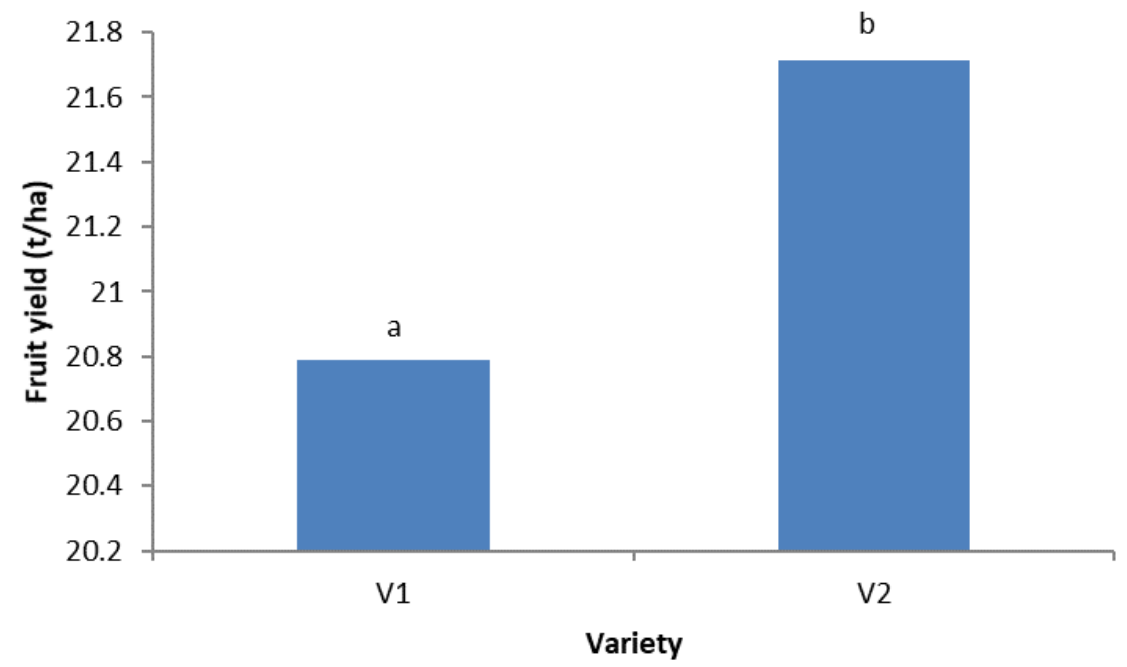

Fig 2: Varietal influence on cucumber fruit yield

Note: Bars with the same alphabet are not significantly different. V1 = Poinsett; V2 = Marketmore

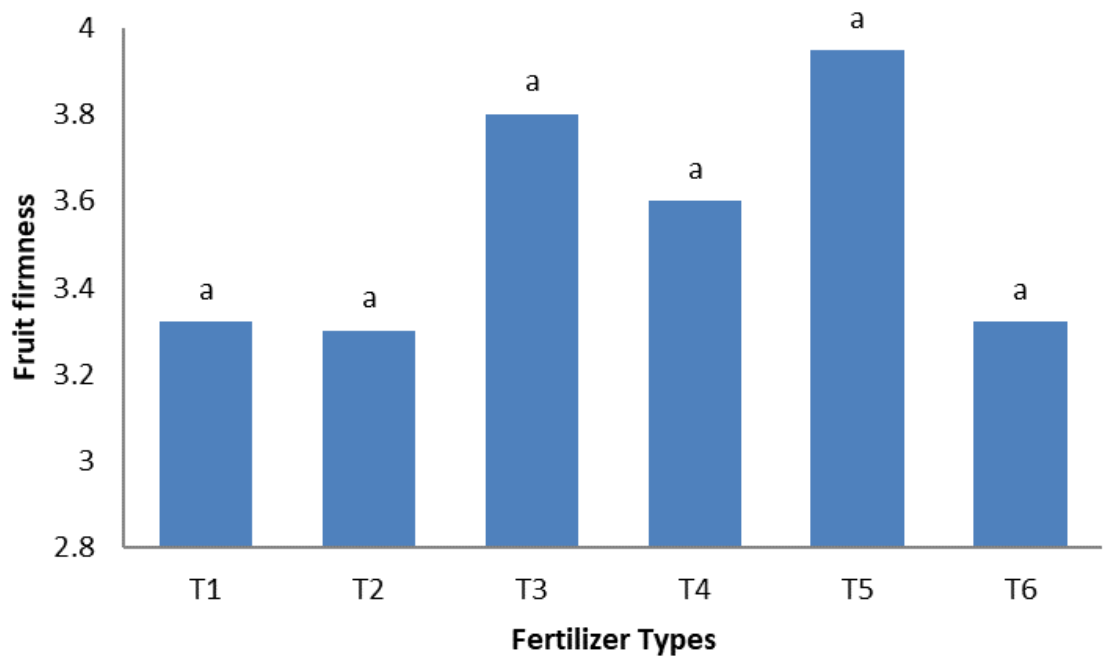

Fig 3: Influence of fertilizer types on the firmness of cucumber fruit Note: Bars with the same letter are not significantly different.

$\mathrm{T} 1=0 \mathrm{~kg} \mathrm{~N} / \mathrm{ha} ; \mathrm{T} 2=100 \% \mathrm{NPK} ; \mathrm{T} 3=100 \%$ Tithonia compost $(\mathrm{TC})$;

$\mathrm{T} 4=50 \% \mathrm{NPK}+50 \% \mathrm{TC} ; \mathrm{T} 5=75 \% \mathrm{NPK}+25 \% \mathrm{TC} ; \mathrm{T} 6=25 \% \mathrm{NPK}+75 \% \mathrm{TC}$ 


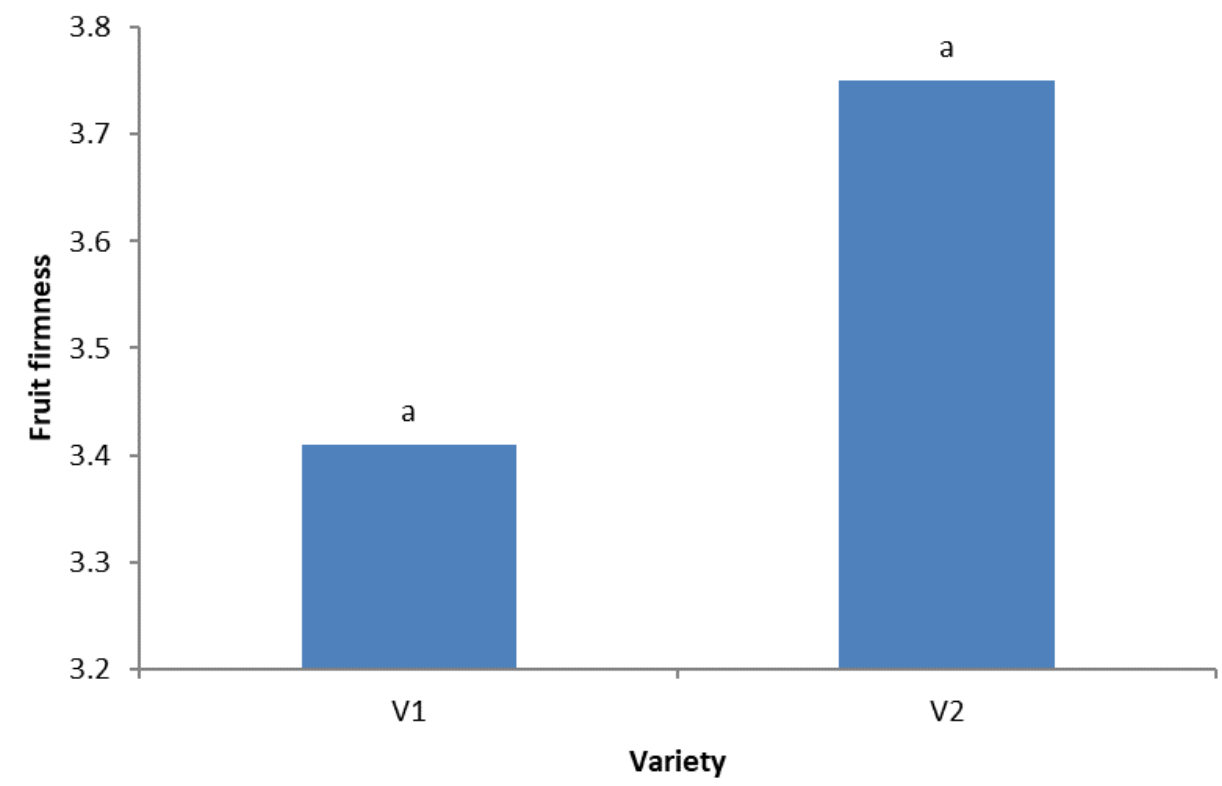

Fig 4: Varietal influence on firmness of cucumber fruit

Note: Bars with the same alphabet are not significantly different $\mathrm{V} 1=$ Poinsett; V2 = Marketmore 